\title{
PROFIL NILAI Neutrophil Lymphocyte RATIO (NLR) PADA PENDERITA DIABETES MELITUS TIPE-2
}

\author{
Profil of the neutrophil lymphocyte ratio (nlr) in type-2 diabetes mellitus \\ Nurdin $^{1}$, Kalma $^{2}$, Hasnawati ${ }^{3}$, Hasnida Nasir ${ }^{4}$ \\ 1.2.3,4 Jurusan Analis Kesehatan Poltekkes Kemenkes Makassar
}

Koresponden : Nurdinanalis@gmail.com

\begin{abstract}
Diabetes Mellitus (DM) Type-2 occurs due to insulin resistance resulting in hyperglycemia. Hyperglycemia will damage the endothelium and cause inflammation. One of the parameters of the inflammation examination, namely the examination of the NLR value, is a parameter for examining inflammatory markers obtained from the neutrophil / lymphocyte value, which is significantly higher in Type-2 DM patients who experience complications. The purpose of this study was to describe the value of NLR in Type-2 Diabetes Mellitus Patients. This research was conducted at the Jaury Jusuf Putera Hospital in Makassar using a Mindray Hematology Analyzer BC-5380. In this study, as many as 30 samples of people with Type-2 DM. This research was conducted using descriptive research. In this study, the results of the examination of the NLR value in patients with Type-2 diabetes were 26 samples $(86.67 \%)$ who experienced an increase in NLR values and as many as 4 samples (13.33\%) who had normal NLR values. Based on these results, it is concluded that the NLR value can be used as a marker of inflammation in people with Type-2 diabetes.

Keywords: Neutrophil Lymphocyte Ratio (NLR) and Type-2 Diabetes Mellitus
\end{abstract}

\begin{abstract}
ABSTRAK
Diabetes Melitus (DM) Tipe-2 terjadi karena resistensi insulin sehingga terjadi hiperglikemia. Hiperglikemia akan merusak endotel dan menyebabkan terjadinya inflamasi. Salah satu parameter pemeriksaan inflamasi yaitu pemeriksaan Nilai NLR, merupakan sebuah parameter pemeriksaan penanda inflamasi yang diperoleh dari nilai neutrofil / nilai limfosit, secara signifikan lebih tinggi pada pasien DM Tipe-2 yang mengalami komplikasi. Tujuan dari penelitian ini yaitu untuk mengetahui gambaran nilai NLR pada Penderita Diabetes Melitus Tipe-2. Penelitian ini dilaksanakan di Rumah Sakit Jaury Jusuf Putera Makassar menggunakan alat Hematology Analyzer Mindray BC-5380. Pada penelitian ini menggunakan sebanyak 30 sampel penderita DM Tipe-2. Penelitian ini dilakukan dengan menggunakan jenis penelitian deskriptif. Pada penelitian ini diperoleh hasil pemeriksaan nilai NLR pada penderita DM Tipe-2 yaitu sebanyak 26 sampel $(86,67 \%)$ yang mengalami peningkatan nilai NLR dan sebanyak 4 sampel $(13,33 \%)$ yang memiliki nilai NLR yang normal. Berdasarkan hasil tersebut disimpulkan bahwa nilai NLR dapat dijadikan sebagai penanda inflamasi pada penderita DM Tipe-2.

Kata Kunci : Neutrophil Lymphocyte Ratio (NLR), Diabetes Melitus Tipe-2
\end{abstract}

\section{PENDAHULUAN}

Diabetes Melitus (DM) merupakan suatu kelompok penyakit metabolik dengan karateristik hiperglikemia yang terjadi karena kelainan sekresi insulin, kerja insulin atau keduanya. Hiperglikemi kronik pada DM berhubungan dengan kerusakan jangka 
panjang, disfungsi, atau kegagalan beberapa organ tubuh, terutama mata, ginjal, saraf jantung dan pembuluh darah (American Diabetes Assosiation, 2015).

Hasil Riset Kesehatan Dasar (Riskesdas) tahun 2018 menunjukkan bahwa secara nasional, prevalensi DM berdasarkan diagnosis dokter pada rentang usia 55-64 tahun menempati posisi tertinggi sebesar $6,3 \%$, disusul usia 65-74 tahun sebesar 6,0\%. Prevalensi nasional DM berdasarkan hasil pengukuran kadar gula darah pada penduduk umur $\geq 15$ tahun yang bertempat tinggal di perkotaan adalah 10,6\% (Kementerian Kesehatan, 2018).

Komplikasi DM jangka panjang tergolong dalam Tipe makrovaskular yang mengacu pada aterosklerosis dengan berkembangnya penyakit arteri koronaria, stroke, penyakit pembuluh darah perifer dan meningkatnya risiko infeksi. Keadaan diabetes merupakan suatu kondisi yang dianggap sebagai keadaan inflamasi sub klinis. Peradangan telah diusulkan sebagai komponen diabetes, pasien dengan DM Tipe-2 tanpa aterosklerosis ditemukan memiliki tingkat reaktanfase akut yang lebih tinggi daripada orang sehat. (Sylvia, 2015).

Inflamasi kronik yang bersifat subklinis telah diketahui memiliki peranan penting dalam progresivitas DM Tipe-2 dan komplikasi kronik pada DM Tipe-2. Sitokin proinflamasi, seperti Interleukin (IL-6) dan Tumor Necrosis Factor $\alpha$ (TNF- $\alpha$ ), berasosiasi dengan disfungsi endotel dan aterosklerosis. CRP dapat meningkat pada keadaan inflamasi seperti pada penyakit rematik, penyakit kardiovaskular, dan infeksi lainnya. Procalcitonin (PCT) untuk melihat respon dari pemberian antibiotika. Beberapa keadaan seperti keganasan, luka bakar, dan infeksi sistemik yang luas dapat meningkatkan kadar PCT. Inflamasi kronik dapat diukur dengan menggunakan penanda hematologi dan biokimiawi, namun sebagian pemeriksaan tersebut kurang praktis dan mahal (Imtiaz dkk, 2012).

Pemeriksaan hitung leukosit merupakan penanda klasik proses inflamasi. Neutrophil Lymphocyte Ratio (NLR) telah menjadi penanda baru inflamasi yang potensial untuk mengetahui adanya inflamasi kronik. NLR adalah marker inflamasi yang dapat dideteksi secara sederhana, efisien dan terpercaya karena stabilitas dan kepekaannya tinggi. Jumlah neutrofil yang tinggi adalah penanda proses peradangan non spesifik destruktif yang sedang terjadi dan jumlah limfosit yang rendah adalah penanda regulasi kekebalan tubuh yang tidak kuat (Azab dkk,2014).

Pada inflamasi kronik, hitung neutrofil akan meningkat dan hitung limfosit akan menurun. Berbagai penelitian menunjukkan bahwa NLR lebih superior dibandingkan hitung leukosit total, hitung neutrofil, atau hitung limfosit sebagai penanda inflamasi karena kurang dipengaruhi oleh berbagai kondisi fisiologis seperti dehidrasi atau aktivitas fisik. Selain itu, pemeriksaan NLR juga memiliki kelebihan dibandingkan penanda inflamasi yang lain, seperti CRP, IL-6, TNF- $\alpha$, dan PCT yaitu mudah dilakukan dan harga relatif murah.

\section{METODE}

Penelitian ini termasuk jenis penelitian deskriptif untuk mengetahui nilai NLR pada penderita DM Tipe- 2 . Penelitian ini dilakukan di Rumah Sakit Jaury Jusuf Putera Makassar pada 09 April-12 Mei 2020.

Populasi pada penelitian ini adalah semua pederita DM Tipe-2 yang ada di Rumah Sakit Jaury Jusuf Putera Makassar. Sampel pada penelitian ini adalah penderita DM Tipe-2 yang ada di Rumah Sakit Jaury Jusuf Putera Makassar yang diambil data sekundernya. Jumlah sampel sebanyak 30 sampel. menggunakan teknik 
pengambilan sampel secara accidental sampling. Instrumen penelitian yang digunakan pada penelitianini adalah data sekunder. Alat dan bahan penelitian yang digunakan dalam penelitian ini adalah Hematology Analyzer Mindray BC-5380, vacutainer, torniquet, darah vena alkohol $70 \%$, kit dilution.

Data penelitian disajikan dalam bentuk tabel dan dianalisa secara deskriptif kemudian dilakukan analisa data menggunakan rumus presentase.

\section{HASIL}

Data hasil NLR pada penderita DM Tipe-2 yang dilakukan terhadap 30 sampel maka diperoleh hasil pemeriksaan sebanyak $26 \quad(86,67 \%)$ sampel yang memiliki nilai NLR yang meningkat dan 4 $(13,33 \%)$ sampel yang memiliki nilai NLR normal.

Data hasil nilai neutrophil dan nilai lymphocyte pada penderita DM Tipe2 yang dilakukan terhadap 30 sampel diperoleh hasil nilai neutrophil meningkat sebanyak 26 sampel,normal sebanyak 4 sampel,dan menurun sebanyak 0 sampel, sedangkan nilai lymphocyte meningkat sebanyak 0 sampel, normal 27 sampel dan menurun 3 sampel.

Pra Analitik antara lain mempersiapkan alat, bahan, pengambilan dan penanganan spesimen darah vena sampai diperoleh serum. Tahapan analitik antara lain Sampel darah harus dipastikan sudah homogen dengan antikoagulan, set hematology analyzer sudah siap digunakan. Pilih work list pada komputer kemudian tekan tombol ID dan masukkan no sampel, tekan enter dan pilih save selanjutnya pilih "RUN" untuk memulai proses pembacaan hasil kemudian buka tutup tabung vacum dan arahkan ke adaptor dan tekan tombol start satu kali kemudian pilih graph maka hasil akan muncul pada layar secara otomatis.

\section{PEMBAHASAN}

Penelitian ini dilakukan pada penderita diabetes melitus Tipe-2 untuk melihat gambaran nilai NLR, dari data yang diperoleh menunjukkan hasil yang signifikan yaitu nilai NLR rata-rata meningkat. Hal tersebut sejalan dengan tujuan penelitian untuk mengetahui nilai NLR pada penderita DM Tipe-2 yang dapat dijadikan sebagai penanda inflamasi yang ditandai dengan peningkatan nilai NLR.

Pada penderita DM Tipe-2 terjadi hiperinsulinemia tetapi insulin tidak bisa membawa glukosa masuk ke dalam jaringan karena terjadi resistensi insulin yang merupakan turunnya kemampuan insulin untuk merangsang pengambilan glukosa oleh jaringan perifer dan untuk menghambat produksi glukosa oleh hati. Akibatnya tejadi peningkatan kadar glukosa darah yang menyebabkan terjadinya kondisi hiperglikemia secara kronis (Fatimah, 2015).

Hiperglikemia yang tejadi dalam jangka panjang menjadi pemicu beberapa komplikasi yang serius. Manifestasi komplikasi kronik dapat terjadi pada tingkat pembuluh darah kecil (mikrovaskuler) dan pembuluh darah besar (makrovaskuler). Komplikasi DM jangka panjang tergolong dalam Tipe makrovaskular yang mengacu pada aterosklerosis dengan berkembangnya penyakit arteri koronaria, stroke, penyakit pembuluh darah perifer dan meningkatnya risiko infeksi (Waspadji, 2015).

Dilihat dari sudut patofisiologi, neutrofil mempresentasikan sistem imun nonspesifik yang menginisiasi respon tubuh terhadap inflamasi, sedangkan limfosit merepresentasikan komponen protektif terhadap inflamasi (Moursy dkk, 2015). Keadaan inflamasi yang berlangsung secara kronik menginduksi hipersekresi sitokin proinflamasi, seperti IL-6 dan TNF- $\alpha$, yang menyebabkan tingginya hitung neutrofil secara menetap (Lou, 2015). Terjadi peningkatan jumlah 
neutrofil (neutrofilia), disertai penurunan limfosit (limfositopenia) pada infeksi. Keadaan neutrofilia terjadi akibat demarginasi, apoptosis yang terlambat, dan terdapat peningkatan stimulasi stem cell G- Colony Stimulating Factor (G$\mathrm{CSF}$ ), sehingga jumlah neutrofil meningkat. Jumlah neutrofil yang tinggi adalah penanda proses peradangan non spesifik destruktif yang sedang terjadi.

Inflamasi dimulai saat sel mast bergranulasi dan melepaskan bahanbahan kimia seperti histamin. Mediator inflamasi yang lain adalah sitokin, yaitu zat-zat yang dikeluarkan oleh leukosit. Sitokin terdiri dari dua kategori yaitu bersifat pro-inflamasi dan antiinflamasi. Sitokin pro-inflamasi antara lain IL-1 yang berasal dari makrofag dan monosit, IL-2, IL-6, TNF- $\alpha$, dan interferon $\gamma$ yang berasal dari aktivitas limfosit. Sitokin proinflamasi berperan dalam merangsang makrofag untuk meningkatkan fagositosis dan merangsang sumsum tulang untuk meningkatkan produksi leukosit dan eritrosit. Pada inflamasi kronik, katekolamin, kortisol, dan mediator proinflamasi meningkat dan akan berikatan dengan reseptor pada permukaan limfosit yang selanjutnya akan menginisiasi apoptosis limfosit sehingga menyebabkan limfopenia. Keadaan limfositopenia terjadi marginasi dan redistribusi limfosit ke sistem limfatik, disertai akselerasi apoptosis. Jumlah limfosit yang rendah adalah penanda regulasi kekebalan tubuh yang tidak adekuat (Azab dkk, 2014).

Selama proses inflamasi sitokinsitokin akan terus diproduksi dan merupakan stimulator dari protein-protein fase akut dan merupakan penanda dari inflamasi kronis yang sering terdeteksi pada penyakit kardiovaskuler, diabetes melitus, osteoarthritis dan rheumatoid arthritis. Sehingga limfopenia tidak akan bertahan lama karena sitokin akan kembali merangsang sumsum tulang untuk memproduksi leukosit yang termasuk didalamnya adalah limfosit.

Hasil penelitian menunjukkan data nilai limfosit normal 27 (90\%) dan menurun $10 \%$. Berdasarkan hasil penelitian dan teori yang ada nilai limfosit tidak dapat menjadi penanda inflamasi karena rata-rata nilia limfosit yang didapat normal, tetapi nilai limfosit dapat dijadikan penanda inflamasi apabila dikorelasikan dengan penanda inflamasi lainnya karena nilai limfosit dapat menurun diakibatkan oleh apoptosis tetapi juga dapat kembali normal karena produksi leukosit yang baru.

Berdasarkan hasil penelitian didapatkan hasil NLR sebanyak 26 $(86,67 \%)$ sampel yang memiliki nilai NLR yang meningkat, sehingga nilai NLR dapat dijadikan sebagai penanda inflamasi pada penderita DM Tipe-2.

Peningkatan nilai NLR tersebut tidak sejalan dengan teori sebelumnya yang menyatakan bahwa terjadinya peningkatan nilai NLR disebabkan peningkatan nilai neutrofil akibat respon tubuh terhadap inflamasi yang menginduksi hipersekresi sitokin proinflamasi dan menurunnya nilai limfosit akibat terjadinya apoptosis. Namun hal tersebut tidak dicapai peneliti dalam penelitian ini karena data yang bersifat data sekunder membatasi peneliti dalam melihat riwayat penderita DM Tipe-2. Keterbatasan peneliti tersebut mempengaruhi nilai neutrofil dan nilai limfosit yang tidak menunjukkan nilai yang signifikan sesuai teori. Meskipun Nilai NLR rata-rata meningkat, akan tetapi peneliti tidak dapat membandingkan penderita DM Tipe-2 yang telah lama terdiagnosa dengan yang baru terdiagnosis.

\section{KESIMPULAN}

Berdasarkan penelitian yang telah dilakukan dengan menggunakan data sekunder dari 30 data penderita DM Tipe2 yang telah diolah menjadi nilai NLR maka diperoleh hasil sebanyak 26 sampel 
$(86,67 \%)$ mengalami peningkatan dan 4 sampel $(13,33 \%)$ sehingga dapat disimpulkan bahwa nilai NLR dapat dijadikan sebagai penanda inflamasi pada penderita DM Tipe-2.

\section{SARAN}

Peneliti selanjutnya melakukan penelitian dengan pengambilan data primer pada penderita diabetes mellitus, peneliti selanjutnya untuk melakukan penelitian tentang perbandingan nilai NLR dengan parameter penanda inflamasi yang lain, klinisi dapat menggunakan nilai NLR sebagai penanda inflamasi.

\section{DAFTAR PUSTAKA}

American Diabetes Association. 2015. Diagnosis and classificat ion of diabetes mellitus. American Diabetes Care, Vol.38, pp: 8-16.

Azab B, Camacho-Rivera M, Taioli E. 2014. Average values and racial differences of neutrophil lymphocyte ratio among a nationally representative sample of United States subjects. PLoS One. 2014;9(11):e112361.

Imtiaz F, Shafique K, Mirza S, Ayoob Z, Vart P, Rao S. 2012. Neutrophil lymphocyte ratio as a measure of systemic inflammation in prevalent chronic diseases in Asian population. Int Arch Med. 5(1):2.

Kemenkes RI, 2018. Riset Kesehatan dasar 2018. Jakarta

Lou M, Luo P, Tang R, Peng Y, Yu S, Huang W. 2015. Relationship between neutrophil-lymphocyte ratio and insulin resistance in newly diagnosed type 2 diabetes mellitus patients. BMC Endocr Disord.15(1):9.

Moursy EY, Megallaa MH, Mouftah RF, Ahmed SM. 2015. Relationship between neutrophillymphocyte ratio and microvascular complications in Egyptian patients with type 2 diabetes. Am J Intern Med.3(6):250-5.

Sylvia, M, Lorraine. 2015. Patofisiologi Edisi 6 Vol 2 Konsep Klinis Proses- Proses Penyakit. Jakarta: EGC

Waspadji, S. 2010. Buku Ajar Ilmu Penyakit Dalam: Komplikasi Kronik Diabetes Melitus. Jakarta: Interna Publishing Pusat Penerbitan Ilmu Penyakit Dalam 
Tabel 1.Hasil Pemeriksaan NLR pada penderita DM Tipe-2

\begin{tabular}{|c|c|c|c|c|c|}
\hline No. & $\begin{array}{l}\text { Kode } \\
\text { Sampel }\end{array}$ & $\begin{array}{c}\text { Nilai } \\
\text { Neutrophil }\end{array}$ & $\begin{array}{c}\text { Nilai } \\
\text { Lymphocyte }\end{array}$ & $\begin{array}{l}\text { Hasil } \\
\quad \text { NLR }\end{array}$ & $\begin{array}{l}\text { Keterangan } \\
\text { hasil NLR }\end{array}$ \\
\hline 1 & $\mathrm{~A}$ & $5,06 \times 10^{3} / \mu 1$ & $2,92 \times 10^{3} / \mu 1$ & 1,73 & Normal \\
\hline 2 & B & $8,65 \times 10^{3} / \mu 1$ & $2,09 \times 10^{3} / \mu 1$ & 4,13 & Meningkat \\
\hline 3 & $\mathrm{C}$ & $13,42 \times 10^{3} / \mu 1$ & $1,16 \times 10^{3} / \mu 1$ & 11,57 & Meningkat \\
\hline 4 & $\mathrm{D}$ & $11,34 \times 10^{3} / \mu 1$ & $1,52 \times 10^{3} / \mu 1$ & 7,46 & Meningkat \\
\hline 5 & $\mathrm{E}$ & $26,15 \times 10^{3} / \mu 1$ & $0,81 \times 10^{3} / \mu 1$ & 32,28 & Meningkat \\
\hline 6 & $\mathrm{~F}$ & $8,04 \times 10^{3} / \mu 1$ & $0,65 \times 10^{3} / \mu 1$ & 12,37 & Meningkat \\
\hline 7 & G & $6,52 \times 10^{3} / \mu 1$ & $3,39 \times 10^{3} / \mu 1$ & 1,65 & Normal \\
\hline 8 & $\mathrm{H}$ & $20,23 \times 10^{3} / \mu 1$ & $0,91 \times 10^{3} / \mu 1$ & 22,23 & Meningkat \\
\hline 9 & I & $10,98 \times 10^{3} / \mu 1$ & $0,89 \times 10^{3} / \mu 1$ & 12,34 & Meningkat \\
\hline 10 & $\mathrm{~J}$ & $20,97 \times 10^{3} / \mu 1$ & $0,65 \times 10^{3} / \mu 1$ & 32,26 & Meningkat \\
\hline 11 & $\mathrm{~K}$ & $12,47 \times 10^{3} / \mu 1$ & $2,21 \times 10^{3} / \mu 1$ & 5,64 & Meningkat \\
\hline 12 & $\mathrm{~L}$ & $18,30 \times 10^{3} / \mu 1$ & $2,30 \times 10^{3} / \mu 1$ & 7,95 & Meningkat \\
\hline 13 & M & $4,81 \times 10^{3} / \mu 1$ & $4,31 \times 10^{3} / \mu 1$ & 1,17 & Normal \\
\hline 14 & $\mathrm{~N}$ & $20,67 \times 10^{3} / \mu 1$ & $1,21 \times 10^{3} / \mu 1$ & 17,08 & Meningkat \\
\hline 15 & $\mathrm{O}$ & $12,16 \times 10^{3} / \mu 1$ & $1,27 \times 10^{3} / \mu 1$ & 9,57 & Meningkat \\
\hline 16 & $\mathrm{P}$ & $8,22 \times 10^{3} / \mu 1$ & $1,73 \times 10^{3} / \mu 1$ & 4,75 & Meningkat \\
\hline 17 & Q & $9,57 \times 10^{3} / \mu 1$ & $2,92 \times 10^{3} / \mu 1$ & 3,27 & Meningkat \\
\hline 18 & $\mathrm{R}$ & $9,76 \times 10^{3} / \mu 1$ & $1,22 \times 10^{3} / \mu 1$ & 8 & Meningkat \\
\hline 19 & $S$ & $21,53 \times 10^{3} / \mu 1$ & $1,56 \times 10^{3} / \mu 1$ & 13,80 & Meningkat \\
\hline 20 & $\mathrm{~T}$ & $11,36 \times 10^{3} / \mu 1$ & $1,84 \times 10^{3} / \mu 1$ & 6,17 & Meningkat \\
\hline 21 & $\mathrm{U}$ & $17,04 \times 10^{3} / \mu 1$ & $1,56 \times 10^{3} / \mu 1$ & 10,92 & Meningkat \\
\hline 22 & $\mathrm{~V}$ & $17,79 \times 10^{3} / \mu 1$ & $1,43 \times 10^{3} / \mu 1$ & 12,44 & Meningkat \\
\hline 23 & $\mathrm{~W}$ & $7,66 \times 10^{3} / \mu 1$ & $2,32 \times 10^{3} / \mu 1$ & 3,30 & Meningkat \\
\hline 24 & $X$ & $12,93 \times 10^{3} / \mu 1$ & $1,75 \times 10^{3} / \mu 1$ & 7,38 & Meningkat \\
\hline 25 & Y & $5,94 \times 10^{3} / \mu 1$ & $1,84 \times 10^{3} / \mu 1$ & 3,22 & Meningkat \\
\hline
\end{tabular}




\begin{tabular}{|c|c|c|c|c|c|}
\hline 26 & $\mathrm{Z}$ & $15,61 \times 10^{3} / \mu 1$ & $0,98 \times 10^{3} / \mu 1$ & 15,92 & Meningkat \\
\hline 27 & AA & $15,65 \times 10^{3} / \mu 1$ & $0,70 \times 10^{3} / \mu 1$ & 22,35 & Meningkat \\
\hline 28 & $\mathrm{AB}$ & $10,78 \times 10^{3} / \mu 1$ & $1,28 \times 10^{3} / \mu 1$ & 8,42 & Meningkat \\
\hline 29 & $\mathrm{AC}$ & $13,11 \times 10^{3} / \mu 1$ & $1,12 \times 10^{3} / \mu 1$ & 11,70 & Meningkat \\
\hline 30 & $\mathrm{AD}$ & $7,18 \times 10^{3} / \mu 1$ & $2,93 \times 10^{3} / \mu 1$ & 2,45 & Normal \\
\hline
\end{tabular}

Tabel.2. Hasil Nilai Neutrophil dan Nilai Lymphocyte pada Penderita DM Tipe-2

\begin{tabular}{lccc}
\hline \multirow{2}{*}{ No. } & Hasil & Neutrophil & Nilai \\
\cline { 3 - 4 } & & 26 & 0 \\
\hline 1 & Meningkat & 4 & 27 \\
2 & Normal & 0 & 3 \\
3 & Menurun & 30 & 30 \\
& Jumlah & & \\
\hline
\end{tabular}

